\title{
METHOD FOR THE MODELING AND STRUCTURING OF COMPUTERIZED NURSING IN INTENSIVE CARE
}

\author{
Daniela Couto Carvalho Barraํ, Sônia Regina Wagner de Almeida², Grace Teresinha Marcon Dal Sasso \\ Fernanda Paese ${ }^{4}$, Greize Cristina Rios ${ }^{5}$
}

\footnotetext{
${ }^{1}$ Ph.D. in Nursing. Professor, Departamento de Enfermagem, Universidade Federal de Santa Catarina (UFSC). Florianópolis, Santa Catarina, Brazil. E-mail: daniela.barra@ufsc.br

${ }^{2}$ M.Sc. in Nursing. Florianópolis, Santa Catarina, Brazil. E-mail: soniarwa@yahoo.com.br

${ }^{3}$ Ph.D. in Nursing. Professor, Departamento de Enfermagem, Programa de Pós-Graduação em Enfermagem (PEN), UFSC. Florianópolis, Santa Catarina, Brazil. E-mail: grace.sasso@ufsc.br

${ }^{4}$ Doctoral student, PEN/UFSC. Florianópolis, Santa Catarina, Brazil. E-mail: fernanda.paese@posgrad@ufsc.br

${ }^{5}$ M.Sc. in Nursing. Florianópolis, Santa Catarina, Brazil. E-mail: greizec@yahoo.com.br
}

\begin{abstract}
Hybrid study of technological production and methodological research aimed at restructuring and organize data and information from the Computerized Nursing Process, based on the International Classification for Nursing Practice (ICNP ${ }^{\circledR}$ ) version 2.0 for Intensive Care Units. Study carried out in four stages: review of conceptual modeling and system logic; grouping of clinical situations in order of increasing complexity; determination of diagnoses and interventions for each clinical situation and; selection and registration of diagnoses and nursing interventions in the computerized system. As a result, 1,349 possibilities for clinical evaluations, 949 diagnoses and 438 nursing interventions were organized, restructured and divided into nine human body systems. The Computerized Nursing Process based on ICNP ${ }^{\circledR}$ can measure results, is adaptable to any reality and allows nurses to use this tool as a structured knowledge base. DESCRIPTORS: Nursing informatics. Nursing process. Classification. Point-of-Care systems. Intensive care units.
\end{abstract}

\section{METODOLOGIA PARA MODELAGEM E ESTRUTURAÇÃO DO PROCESSO DE ENFERMAGEM INFORMATIZADO EM TERAPIA INTENSIVA}

RESUMO: Estudo híbrido de produção tecnológica e pesquisa metodológica que objetivou reestruturar e organizar os dados e informações do Processo de Enfermagem Informatizado, a partir da Classificação Internacional para as Práticas de Enfermagem (CIPE $\left.{ }^{\circledR}\right)$ versão 2.0 para Unidades de Terapia Intensiva. Estudo desenvolvido em quatro etapas: revisão da modelagem conceitual e lógica do sistema; agrupamento de situações clínicas por ordem de complexidade crescente; determinação de diagnósticos e intervenções para cada situação clínica; e seleção e cadastro dos diagnósticos e intervenções de enfermagem no sistema informatizado. Obteve-se, como resultado, a organização de 1.349 possibilidades de avaliações clínicas, 949 diagnósticos e 438 intervenções de enfermagem, reestruturadas e distribuídas em nove sistemas do corpo humano. O Processo de Enfermagem Informatizado baseado na CIPE pode mensurar resultados, é adaptável a qualquer realidade e permite ao enfermeiro utilizar esta ferramenta como base estruturada de conhecimento.

DESCRITORES: Informática em enfermagem. Processos de enfermagem. Classificação. Sistemas automatizados de assistência junto ao leito. Unidades de terapia intensiva.

\section{METODOLOGÍA PARA EL MODELADO Y ESTRUCTURA DEL PROCESO DE ENFERMERÍA COMPUTARIZADO EN CUIDADOS INTENSIVOS}

RESUMEN: Estudio híbrido de producción tecnológica e investigación metodológica que tuvo por objetivo reestructurar y organizar los datos e información del Proceso de Enfermería Computarizada de la Clasificación Internacional para la Práctica de Enfermería $\left(\mathrm{CIPE}^{\circledR}\right)$ Versión 2.0 en unidades de cuidados intensivos. Estudio realizado en cuatro etapas: revisión de modelado conceptual y lógica del sistema; agrupación de situaciones clínicas en orden de complejidad creciente; determinar los diagnósticos e intervenciones para cada situación clínica y; selección y registro de diagnósticos e intervenciones de enfermería en el sistema informatizado. Se obtuvo como resultado la organización de 1.349 posibilidades para las evaluaciones clínicas, 949 diagnósticos y 438 intervenciones de enfermería, reestructurados y distribuidas en nueve sistemas del cuerpo humano. El Proceso de Enfermería Informatizado basado en CIPE ${ }^{\circledR}$ puede medir los resultados, es adaptable a cualquier realidad y permite a las enfermeras a utilizar esta herramienta como base estructura de su conocimiento.

DESCRIPTORES: Informática aplicada a la enfermería. Procesos de enfermería. Clasificación. Sistemas de atención de punto. Unidades de terapia intensiva. 


\section{INTRODUCTION}

Health care faces new and complex challenges around the world. Among these, the continuing growth in the number of people is highlighted, which has accompanied the advancement of technologies and knowledge in health, aiming to improve the prevention processes of diseases, health promotion, treatment and rehabilitation. This development pressures the health care system to improve the quality and reduce the costs. To achieve such ambitious target, among other aspects, information systems and informatics technologies are needed, which efficiently integrate the cooperation among different health professionals in the targets to improve the population's health and in the highest quality levels of the patients' treatment process.

In the age of information and communication technologies (ICTs), computers have become fundamental in health services, especially due to: the need to process a large amount of information in a short time interval; speed and safety in the access to and organization of the information, independently of the time and place; and improvement in the organization of the patient data and information. The above illustrates the growing importance and concern with the development of efficient information systems, which permit advances in service management, increased productivity and improvements in the quality of care delivery. ${ }^{1-5}$

Nursing can use the ICTs to establish, in the care environment, the Computerized Nursing Process (CNP) in intensive care. At a sector like the Intensive Care Unit (ICU), the CNP integrates, organizes and guarantees the continuity of the nursing team's information; it permits efficacy and effectiveness assessments, modifications according to the outcomes of patient recovery; and provides a permanent background for nursing education, research and management. ${ }^{2,6}$

To integrate the data and clinical information from the nursing process of $\mathrm{CNP}$, the different types of standards, terminologies or nursing classification systems developed in recent years need to be aligned in order to provide interoperable and mutually comparable data. ${ }^{2,7-8}$

In this context, the International Classification for Nursing Practice (ICNP ${ }^{\circledR}$ ), elaborated by the International Council of Nurses (ICN), stands out because of its standardization and structure ready for computerization, consisting of terms and definitions that permit the construction of nursing diagnoses, interventions and outcomes to document nursing care. It is also highlighted that this classification adopts the standard ISO 18.104, published in 2003, which addresses the reference terminology model for nursing diagnoses and actions. Eight versions of the ICNP ${ }^{\circledR}$ have been published since 1996, the most recent of which is called ICNP ${ }^{\oplus}$ version 2013.9-12

In view of these considerations, since 1999, several studies have developed, improved and assessed the CNP in accordance with the ICNP ${ }^{\circledR}$. Those studies permitted the construction of an information structure available via web (fixed environment) and via mobile devices like a Personal Digital Assistant (PDA) (integrated into the computer system via web) considering the data and clinical information, nursing diagnoses, interventions and outcomes to register nursing care for the documentation of ICU nursing care. ${ }^{26,613-14}$ In this study, the CNP for ICUs is structured based on version 2, the most recent version translated to Portuguese by the Portuguese Order of Nurses, in 2011.

With the positive assessment of nurses, computer and/or intensive care expert teachers and system programmers, new recommendations for future studies were suggested, including the updating and restructuring of the data and information from the CNP for the web and mobile devices. In that sense, the goal in this study was to restructure and organize the data and information from a CNP based on $\mathrm{ICNP}^{\circledR}$ version 2.0 for ICUs.

\section{METHOD}

Hybrid study of technological production and methodological research ${ }^{15} \mathrm{on}$ the restructuring of the data and information from the CNP for ICUs, available via web in desktop environments and in mobile devices. The data and information were restructured and organized to update, complement and adapt the CNP for the purpose of better application and use in adult ICUs.

The study participants were one teacher and four graduate nursing students. The participants are experts in ICU and Emergency care and have developed research involving the ICNP ${ }^{\circledR}$ in the Group for Clinical Research, technologies and Informatics in Health and Nursing (GIATE/PEN/ UFSC) since 2003.

This study was submitted to the Etichal Research Committee at Universidade Federal de Santa 
Catarina and received approval without any exemptions (protocol 947/10). It is highlighted that this study refers to one of the specific objectives of the research, entitled "Computerized nursing process and patient safety in intensive care based on the $\mathrm{ICNP}^{\circledR}$ version 1.0: clinical evidence for care". In the phases after the modeling and structuring of the computer system, nurses, teachers and system programmers assessed the study, therefore requiring preliminary approval by the Etichal Research Committee.

The study was developed between May and August 2011 in four phases, explained next:

$1^{\text {st }}$ phase: review of the conceptual and logical modeling of the computer system. These two structures were developed simultaneously. The data modeling followed the conceptual entity-relationship model, containing 35 entities in a structure represented by the tables (which demonstrate the relationship between the data), operations, and by the relationships, using the Structured Query Language (SQL). This is a declarative research language for a relational database. This relational database model defines ways to store, manipulate and recover data solely structure in the form of tables, appropriate to serve as the underlying model of a Database Management System. ${ }^{16}$

To give an example, the primary keys representing the attributes that identify the entity, used in the structure of this database, were: id_prontuário; id_avaliações; id_diagnósticos; id_intervenções (for the different human systems), id_fluidoterapia, among others. The foreign key, in turn, which can also be one or several attributes, is used to refer to entities in other tables and considers the values of the primary key in the referred table. Examples are:

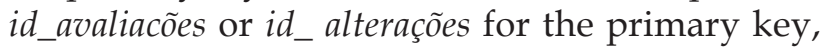
id_diagnósticos and so forth. Therefore, all entities in the conceptual model turned into tables in the logical project and tables were also added to feed the data forms.

$2^{\text {nd }}$ phase: grouping of different clinical situations in order of complexity/severity, used for the association, articulation and restructuring of the data, aiming to address all items o the patient's clinical assessment. Three to four groups of clinical situations were structured for each human system, specified as follows: three clinical situations for the musculoskeletal, integumentary, biopsychosocial, gastrointestinal, male reproductive and female reproductive systems and four for the respiratory, cardiovascular, neurological and renal systems.
The latter human systems considered four clinical situations, especially due to the larger data volume and clinical assessment information. The grouping of the clinical situations for each human system was based on cases of patients hospitalized at the ICU. This phase was developed based on the study participants' professional experience, reasoning and clinical judgment, being therefore a theoreticalconceptual cluster.

$3^{\text {rd }}$ phase: determination of a group of nursing diagnoses and interventions based on the ICNP ${ }^{\circledR}$ version 2.0 for each clinical situation elaborated. This phase was developed through weekly meetings and again required that the nurses integrated professional practice and theory, the development of clinical reasoning and clinical judgment, through the countless possible associations that could be made in accordance with each clinical condition of patients in critical health conditions.

$4^{\text {th }}$ phase: selection and registration of nursing diagnoses and interventions directly in the computer system. For each diagnosis, in each human system, the corresponding interventions were selected and registered. It should be highlighted that, for countless nursing diagnoses, different interventions could be selected, which could address one or more diagnoses. Thus, a detailed reading of all interventions was needed for each diagnosis registered in the CNP. The number of interventions varied according to the nursing diagnosis. In this phase, a wide-ranging and in-depth review of the data, diagnoses and interventions in the CNP was done. The system was immediately updated, so that diagnoses without corresponding or with repeated and/or outdated interventions were excluded.

\section{RESULTS}

After the updates and restructuring of the $\mathrm{CNP}$, that is, the association and registration of the clinical assessment, nursing diagnosis and intervention data, the system went through significant, relevant and innovative modifications for nursing care in ICUs. When the nurse selects the clinical assessment data and information from a certain human system, the CNP offers a group of possible diagnoses for the clinical assessment made, thus supporting his/her decision making. It is highlighted that the other diagnoses the system did not address or suggest are available for research in a link at the end of the diagnoses listed. 
The same restructuring was undertaken for the nursing diagnoses, that is, when a diagnosis is selected, the system offers the interventions corresponding to that diagnosis. The nurse can disregard an intervention if the patient, because of some characteristic and/or clinical change, does not need that intervention. Like on the diagnosis screen, at the bottom of the nursing interventions screen, a link is displayed to access the other human system interventions. Thus, as the data and information structure was organized, it was immediately restructured and incorporated in the system design, as can be observed in Figures 1 and 2 .

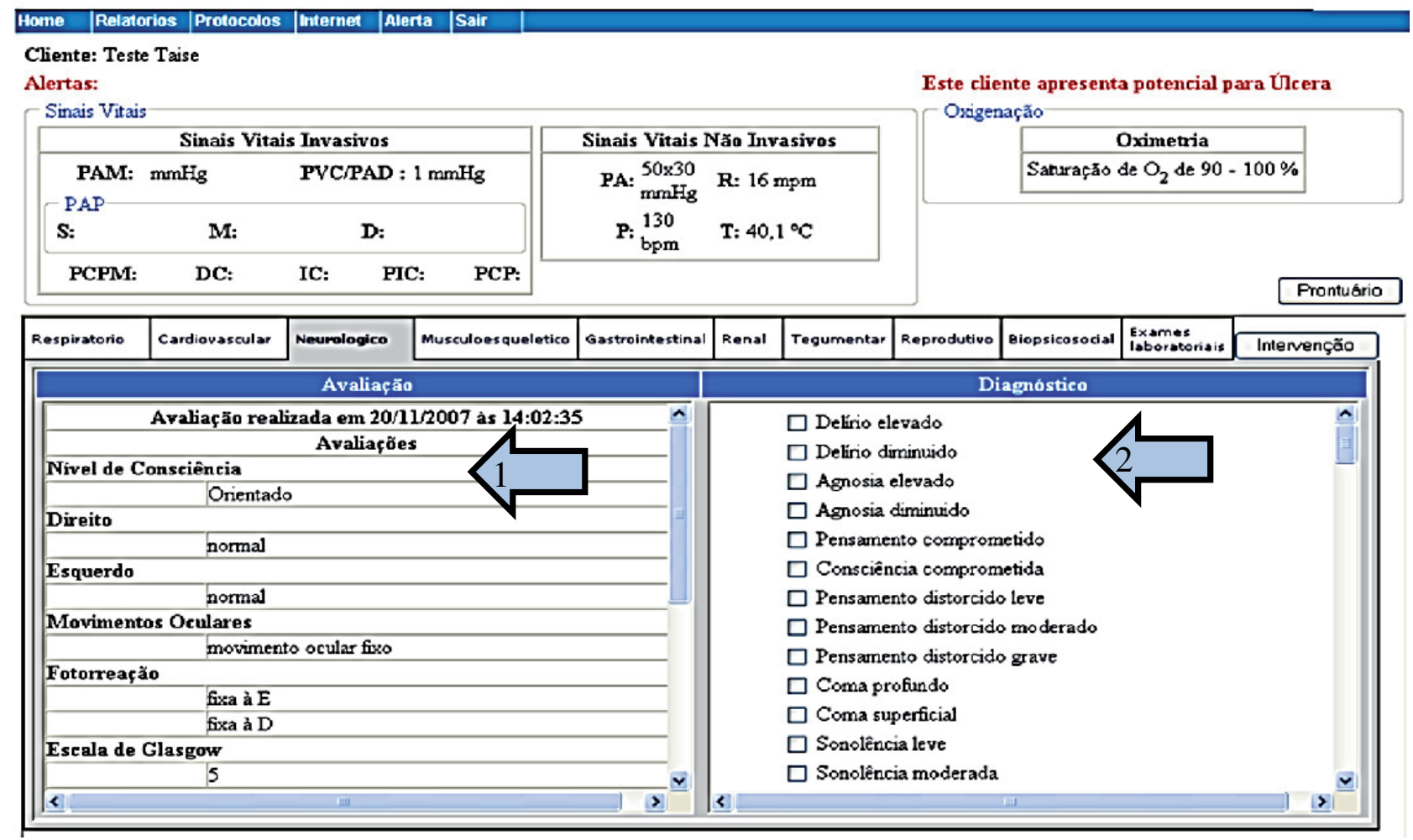

Legend: arrow 1: clinical assessment screen of neurological system; arrow 2: diagnosis screen suggested by CNP based on the nurse's clinical assessment

Figure 1 - Screen with clinical assessment and nursing diagnoses for neurological system in the CNP. Florianópolis-SC, 2011 
Home Relatorios Protocolos Internet Alerta Sair

Cliente: Teste Taise

Alertas:

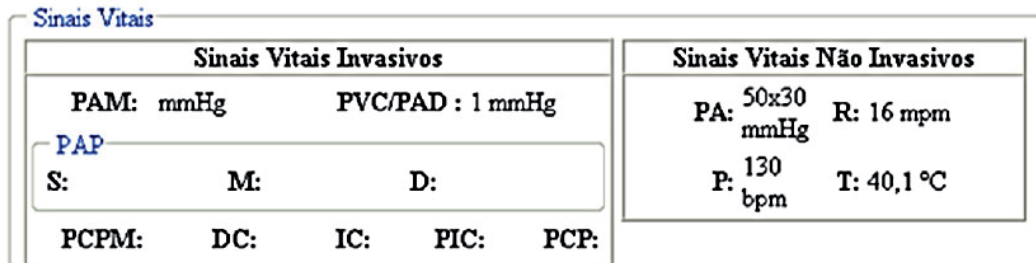

Este cliente apresenta potencial para Úlcera

- Oxigenação

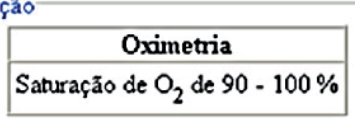

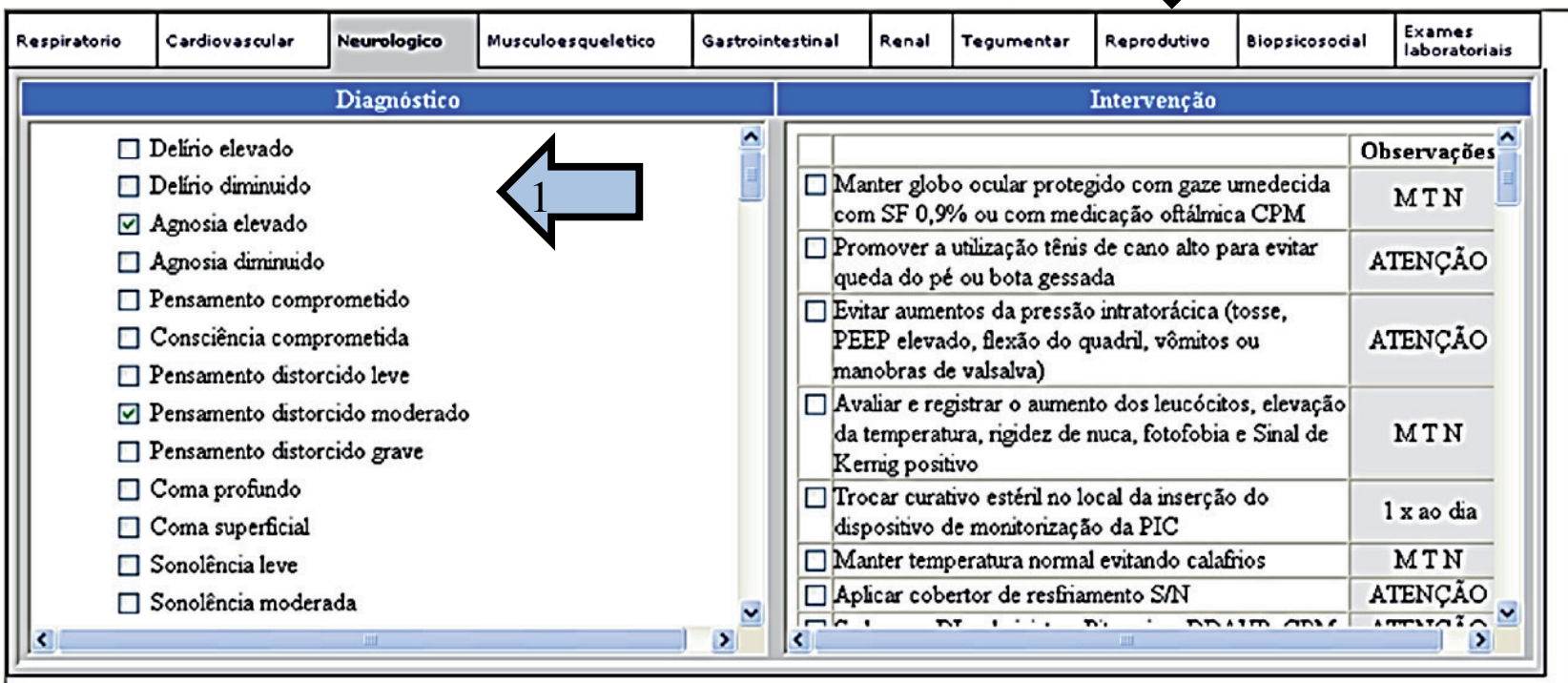

Legend: arrow 1: nursing diagnosis screen; arrow 2: screen with nursing interventions suggested by CNP based on the diagnoses selected by the nurse

Figure 2 - Screen with nursing diagnoses and interventions for neurological system in the CNP. Florianópolis-SC, 2011

To permit the electronic assignation of the nursing interventions, to the left of each intervention, space was provided for the nurse to click and access a box with figures from 1 to 24 , representing the time. The nurse chooses at what time that intervention is necessary, and these times are immediately transferred to the specific space of the intervention.

The restructuring and organization of the CNP resulted in 1,349 clinical assessment possibilities, 949 diagnoses and 438 nursing interventions, in accordance with the ICNP ${ }^{\circledR} 2.0$, distributed among the nine human body systems, as shown in Table 1 .

Table 1 - Distribution of number of nursing assessments, diagnoses and interventions in the CNP per human system. Florianópolis-SC, Brazil, 2011

\begin{tabular}{lccc}
\hline Human systems & Clinical assessments & Nursing diagnoses & Nursing interventions \\
\hline Respiratory & 151 & 78 & 53 \\
Cardiovascular & 145 & 177 & 84 \\
Neurological & 164 & 106 & 49 \\
Integumentary & 223 & 112 & 27 \\
Gastrointestinal & 152 & 75 & 74 \\
Renal & 60 & 43 & 57 \\
Musculoskeletal & 243 & 111 & 46 \\
Female and male reproductive & 151 & 97 & 26 \\
Biopsychosocial & 60 & 145 & 22 \\
\hline Total & 1,349 & 949 & 438 \\
\hline
\end{tabular}


It is highlighted that, due to the scientific and technological advances, evidence-based practice and the consequent complexity of ICU care, many updated nursing interventions were added to the CNP. To give an example, the nursing interventions related to the verification of intra-abdominal pressure are mentioned. This procedure is relatively recent in nursing care and was not part of the data and information in the system yet. Two diagnoses and four interventions related to this care were added.

\section{DISCUSSION}

The ICTs have turned into a very important tool to improve the access to, cost and quality of health care. The ICTs support the systematic documentation of care and permit the filing of data on the health care services, resources and patient outcomes in repositories that can be accessed and analyzed to assess the health care and produce new knowledge. The ICTs also facilitate the nurses' access to the data and to evidence. ${ }^{16}$

The complexity of the information in the globalized world is redefining and creating new characteristics of health care, representing a current challenge for health and nursing. Therefore, the data and information from the CNP need to be assessed and modified whenever necessary, with a view to the development of safe and evidence-based nursing care. ${ }^{6}$

The data and information on the clinical assessment, nursing diagnoses and interventions were associated and restructured according to the experience of the professionals who were part of the study and were confirmed through an exhaustive search in recent reference literature, in search of new scientific evidence. This experience is based on critical thinking, in which the professional uses purposeful and self-regulatory judgment, integrated in cognitive tools such as: interpretation, analysis, inference, assessment and explanation of the supporting, conceptual, methodological or contextual considerations the judgment is based on. ${ }^{19-22}$

Based on the modeling, restructuring and organization of the computerized data and information, the nurse can deliver better quality and safer care, as the largest possible number of clinical assessments, nursing diagnoses and interventions could be related and integrated. This restructuring permitted a range of suggestions for assessment, diagnostic and interventions items or care for the purpose of support and decision making in the clinical practice of ICU nurses.
The development, application and assessment of a nursing terminology integrated into the electronic health record are priorities for the development of nursing. The aggregation of a standardized terminology like the ICNP ${ }^{\square}$ enables the nurse to test the validity and reliability of the knowledge representation. This knowledge representation, through the extraction of data and information, is used to support clinical decision making and the development of specific nursing resarch. ${ }^{23}$ In a study developed in Sweden with 85 nurses, it was concluded that one of the prerequisites to enhance the quality of care is the maintained quality of standardized care plans through computerization. ${ }^{24}$

The current structure and modeling, associated with the ICNP ${ }^{\square}$ as the knowledge base, contribute to patient safety, as the electronic health record through the CNP improves communication, makes data, information and knowledge accessible, supports clinical decision making, facilitates a rapid response, reduces errors, follows trends by means of updated guidelines and evidence, permits remote access to multiple users and avoids orthographic errors and abbreviations. ${ }^{3,14,19,25-29}$ In other words, each technology that is added to care and to the organization system increases the complexity of nursing work, although it also makes possible the reduction of the workload, improving the quality of care and reducing errors and adverse events. ${ }^{30}$

In the methodological phases adopted for the modeling, restructuring and organization of the system, phase 2 involved the elaboration of specific clinical situations, involving a ranking of complexity of a fictitious patient's clinical problems. In other words, clinical situation 1 always referred to a patient with his compensated clinical functions (in each human system), which resulted in few nursing diagnoses and interventions); in the final situation (situation 3 or 4 , according to the human system assessed), the patient presented severe problems or decompensations in his clinical functions, resulting in various nursing diagnoses and interventions.

In the third phase, the composition and review of the nursing diagnoses was organized in compliance with the declaration of the ICNP ${ }^{\circledR}$ Catalogue recommends the inclusion of at least one term from the Focus Axis and one term from the Judgment Axis. The same happened with the review of the nursing interventions, that is, the declaration of the ICNP ${ }^{\circledR}$ Catalogue was complied with, including one term from the Action Axis and at least one term from any of the other axes, except for the Judgment Axis. ${ }^{17}$ After this review and the composition of new 
and updated nursing diagnoses and interventions, the researchers determined the proper clusters for each human system. In this phase, the number of interventions for each diagnosis greatly varied. As an example of this variation, it was observed that, for the nursing diagnosis "mild amnesia" (neurological system), only one intervention was registered. For the nursing diagnosis "severe ischemic pain" (cardiovascular system), 23 interventions were registered.

To cluster and associate the clinical situations with the respective nursing diagnoses and interventions, clinical reasoning and judgment were continuously used, based on the clinical experience of each research participants. Thus, the intent was to dynamically develop schematic and logical reasoning to analyze and make decisions on the different clinical situations and contexts of complex patient care.

It is highlighted that, based on the method for the modeling and structuring of the computerized nursing process in intensive care developed in this study, in a subsequent phase, the usability, ergonomics, cognitive workload and time spent to practice the nursing process based on the ICNP ${ }^{\circledR} 2.0$ could be analyzed.

\section{CONCLUSIONS}

The restructuring and organization of the $\mathrm{CNP}$ resulted in 1,349 possible clinical assessments, 949 diagnoses and 438 interventions, distributed among the nine human body systems, evidencing that the nursing process based on the ICNP ${ }^{\circledR}$ version 2.0 can not only be computerized and measure outcomes, but can also be adapted to any reality and allows the nurse to use this tool as a structured knowledge base.

When using the $\mathrm{ICNP}^{\circledR}$, it is considered that, by concretely associating the clinical assessments, Nursing diagnoses, interventions and outcomes, the nurses organize and develop clinical reasoning in the care process of ICU patients.

It is highlighted that the application of the current structure and modeling of the CNP is focused on ICUs and Emergency services. Nevertheless, the structured database permits the expansion of the system to the other nursing care environments. The data and information stored permit future studies, such as: construction and measuring of quality indicators for patient safety; integration with different hospital information systems through the electronic patient file and; measuring of the outcomes of nurs- ing interventions in patients' different clinical situations based on diagnostic changes.

\section{REFERENCES}

1. Englebright J, Aldrich K, Taylor CR. Defining and incorporating basic nursing care actions into the electronic health record. J Nur Scholarsh. 2014; 46(1):50-7.

2. Sasso GTMD, Barra DCC, Paese F, Almeida SRWA, Rios GC, Marinho MM, et al. Computerized nursing process: methodology to establish associations between clinical assessment, diagnosis, interventions, and outcomes. Rev Esc Enferm USP. 2013; 47(1):242-9.

3. Filipova AA. Electronic health records use and barriers and benefits to use in skilled nursing facilities. Comput Inform Nurs. 2013; 31(7):305-18.

4. Peres HHC, Lima AFC, Cruz DALM, Gaidzinski RR, Oliveira NB, Ortiz DCF, et al. Assessment of an electronic system for clinical nursing documentation. Acta Paul Enferm. 2012; 25(4):543-8.

5. Piscotty Jr RJ, Kalisch B, Gracey-Thomas A. Impact of healthcare information technology on nursing practice. J Nur Scholarsh. 2015; 47(4):287-93.

6. Barra DCC, Sasso GTMD. Tecnologia móvel à beira do leito: processo de enfermagem informatizado em terapia intensiva a partir da CIPE 1.0®. Texto Contexto Enferm. 2010; 19(1):54-63.

7. Hovenga EJS. Importance of achieving semantic interoperability for national health information systems. Texto Contexto Enferm. 2008; 17(1):158-67.

8. Matney SA, Dadamio R, Couderc C, Dlugos M, Evans J, Gianonne G, et al. Translation and Integration of CCC Nursing Diagnoses into ICNP. J Am Med Inform Assoc. 2008; 15(6):791-3.

9. Barra DCC, Sasso GTMD. The nursing process according to the international classification for nursing practice: an integrative review. Texto Contexto Enferm. 2012; 21(2):440-7.

10. Marin HF. Terminologia de referência em enfermagem: a Norma ISO 18104. Acta Paul Enferm. 2009; 22(4):4458.

11. Cubas MR, Denipote AGM, Malucelli A, Nóbrega MML. The ISO 18.104: 2003 as integrative model of nursing terminologies. Rev Latino-Am Enfermagem. 2010; 18(4):669-74.

12. Carvalho CMG, Cubas MR, Malucelli A, Nóbrega MML. Alignment of ICNP® 2.0 Ontology and a proposed INCP ${ }^{\circledR}$ Brazilian Ontology. Rev Latino-Am Enfermagem. 2014; 22(3):499-503.

13. Sasso GMD, Barra DCC. Cognitive workload of computerized nursing process in intensive care units. Comput Inform Nurs. 2015; 33(8):339-45.

14. Barra DCC, Sasso GTMD, Baccin CRA. Warning systems in a computerized nursing process for 
intensive care units. Rev Esc Enferm USP. 2014; 48(1):125-32.

15. Abedellah FG, Levine E. Better patient care through nursing research. New York (US): MacMillan; 1965.

16. Elmasri R, Navathe SB. Sistemas de banco de dados. São Paulo: Pearson Addison Wesley; 2005, 724 p.

17. International Council of Nurses. Classificação Internacional para a Prática de Enfermagem - CIPE versão 2.0. Lisboa (PT): Ordem dos Enfermeiros; 2011.

18. Facione PA. Critical thinking: a statement of expert consensus for purposes of educational assessment and instruction - the Delphi Report. Millbrae: California Academic Press; 1990 [cited 2014 Agu 30]. Available from: http:/ /assessment.aas.duke.edu/documents/ Delphi_Report.pdf

19. Day L. Evidence-based practice, rule-following, and nursing expertise. Am J Crit Care. 2009; 18(5):479-82.

20. Seckman C, Fisher C, Demner-Fushman D. Outstanding poster-research: evaluation of a decision support tool for evidence-based practice. Comput Inform Nurs. 2013; 31(9):410.

21. Khong PCB, Hoi SY, Holroyd EM. Nurses' clinical decision making on adopting a wound clinical decision support system. Comput Inform Nurs. 2015; 33(7):295-305.

22. Jae LJ, Hyeon-Cheol J, Kyung-Ah K, Ye-Jean K, Myung-Nan L. Development of a simulation scenario and evaluation checklist for patients with asthma in emergency care. Comput Inform Nurs. 2015; 33(12):546-54.
23. Barra DCC, Sasso GTMD. Padrões de dados, terminologias e sistemas de classificação para o cuidado em saúde e enfermagem. Rev Bras Enferm. 2011; 64(6):1141-9.

24. Dahm MF, Wadensten B. Nurses' experiences of and opinions about using standardised care plans in eletronic health records - a questionnaire study. J Clin Nurs. 2008; 17(6):2137-45.

25. Detwiller M, Petillion W. Change management and clinical engagement: critical elements for a successful clinical information system implementation. Comput Inform Nurs. 2014; 32(6):267-73.

26. Carrington JM, Effken JA. Strengths and limitations of the electronic health record for documenting clinical events. Comput Inform Nurs. 2011; 29(6):360-7.

27. Sousa PAF, Sasso GTMD, Barra DCC. Contributions of the electronic health records to the safety of intensive care unit patients: an integrative review. Texto Contexto Enferm. 2012; 21(4):971-9.

28. Barra DCC, Sasso GTMD, Almeida SRW. Usabilidade do processo de enfermagem informatizado a partir da CIPE ${ }^{\circledR}$ em unidades de terapia intensiva. Rev Esc Enferm USP. 2015; 49(2):326-34.

29. Byrne MD, Lang N. Examination of nursing data elements from evidence-based recommendations for clinical decision support. Comput Inform Nurs. 2013; 31(12):605-14.

30. Zuzelo PR, Gettis C, Hansell AW, Thomas L. Describing the influence of technologies on registered nurses' work. Clin Nurse Spec. 2008; 22(3):132-40. 